\title{
Research and Investigation on Learning Experience of Ideological and Political Course for Social Science Students
}

\author{
Wenbin Li \\ School of Marxist, China University of Mining and Technology, Xuzhou, Jiangsu, China
}

\begin{abstract}
Teaching effect of ideological and political courses can be practically enhanced by developing investigation and research on the learning experience of social science students. Being the most critical course in their study life, ideological and political learning, from the practical researches, is considered to have a high satisfying level. However, there are different attitudes towards some teaching details and measures. Questionnaire survey and random interview are adopted in this article to judge the learning experience of the courses for social science students from the actual data. Some suggestions are put forward for developing the course system for reference.
\end{abstract}

Keywords: social science students; ideological and political classroom; learning experience; classroom construction

\section{Introduction}

Ideological and political course is a hot topic in education currently. After the implementation of the new curriculum reform, ideological and political course is actively seeking reform and development in order to find specific ways to improve teaching quality and learning experience. However, practically speaking, the learning experience for social science students in ideological and political courses is not ideal. Therefore, it is necessary to make appropriate changes in teaching content and process from the perspective of students. Through such methods, the teaching effect can be brought into full play and classroom teaching quality can be improved steadily.

\section{Current Status of Students' Learning Experience in Students' Ideological and Political} \section{Classes}

Ideological and political courses in colleges and universities are mainly for cultivating students' ideological and moral qualities, and carrying out moral education. That is to say, the ideological and political course is the main stage for moral education in university period. The subject is the foundation of moral education, and features heavy tasks currently. Therefore, enhancing the construction of the course is popular at present. In order to improve the learning experience, it is necessary to improve and optimize the teaching process system from the perspective of teachers and students, which consist the main subjects of the classroom. However, there are relatively few studies on the learning experience of ideological and political courses in China. In order to improve the teaching effect, we should learn from the research results abroad and introduce the judgment index of learning experience of courses in the process of evaluating the quality of courses. However, it should be noted that the course learning experience can be used to judge the quality of classroom

Copyright (C) 2020 by author(s) and Frontier Scientific Research Publishing Inc.

This work is licensed under the Creative Commons Attribution International License (CC BY 4.0).

http://creativecommons.org/licenses/by/4.0/ 
teaching activities as one of the criteria instead of the only one. On the whole, the existing research and investigation on the learning experience mainly focuses on the dimensions of curriculum objectives, teaching content, student satisfaction, student learning, etc., and the investigation results are also countermeasures for some common problems, which are of low referential value. In this regard, the author, by taking social science students as the main investigation object, learns about the current situation of their learning experience, and judges whether there are differences in learning experience among students in different years, and whether factors, such as curriculum objectives and teaching contents, will have an impact on curriculum learning experience.

\section{Research on Social Science Students' Learning Experience in Ideological and Political}

\section{Courses}

\subsection{Tools and objects}

With the help of foreign college students' curriculum learning experience questionnaire, combined with the actual situation of education and teaching effect, the test was conducted on the social science majors of University A. In order to ensure the validity of the survey data, invalid questionnaires were removed from the collected 300 questionnaires, and the final valid questionnaires were 260 , with a recovery rate of $86.66 \%$. Some students were interviewed face-to-face or by telephone to ensure the reality of results. University A has a long history, and its overall teaching level of social science majors ranks among the top in China. As a local comprehensive university, its ideological and political teaching system is relatively complete with few influencing factors. The 300 questionnaires distributed in this survey covered students from freshmen to juniors majoring in social sciences. The percentages of freshmen to juniors in effective questionnaire were $43.5 \%, 29.5 \%$ and $27.0 \%$ respectively. Besides, there are 58 males and 202 females in this questionnaire. There are 18 small items in the questionnaire, including the goal, assessment, teaching, burden and skills. From $\alpha$ coefficient, the data has high credibility. Moreover, a small number of students majoring in science and engineering and art were investigated in order to compare with students majoring in social science. In this case, the difference analysis is realized and the accuracy of the results is ensured. That is to say, in addition to the 260 questionnaires provided to students majoring in social sciences, 30 students from other majors were randomly selected to participate in the questionnaire survey, and 28 valid reports were finally obtained.

\subsection{Results and data analysis}

\subsubsection{Data analysis of learning experience of students majoring in social sciences}

From the overall satisfaction of the course, 188 out of 260 students majoring in social science chose "quite agree" and "very agree" on the issue of "I am satisfied with the teaching quality of ideological and political class", accounting for $72.31 \%$, with an average score of 4.21 . Thus, these students are satisfied with the current teaching quality of ideological and political class. While 20 out of 28 students from other majors chose "quite agree" and "very agree", accounting for $72.30 \%$.

Table 1 and Table 2 are the topics with higher average score and lower average score in this questionnaire respectively. It can be said that the teaching advantages in the current ideological and political class and the teaching details need to be improved. It can be seen from the data that students majoring in social sciences have clear teaching objectives, which means that the basic task of imparting knowledge has been completed in classroom teaching. In addition, it can be seen from the high score items that teachers majoring in social sciences have initially met the teaching standards and requirements put forward after the new curriculum reform. The classroom atmosphere is active and the teaching objectives are clear, which enables students to have a good learning experience in classroom. However, it is found in the low scores issue that the academic burden of social science students is heavy, and the way of evaluation is rather rigid and 
boring. After further interview and investigation, it is found that many students' homework even won't get feedback from teachers. In addition, the evaluation is mainly based on closed-book knowledge questions and answers, supplemented by research and thesis writing. However, non-knowledge memory tests are more popular among social science students actually.

Table 1. Content of high grouping topics

\begin{tabular}{|c|c|c|}
\hline Investigation topic & Mean value (m) & Standard deviation (SD) \\
\hline Explain the knowledge content clearly in class & 3.58 & 0.82 \\
\hline $\begin{array}{c}\text { The atmosphere of ideological and political } \\
\text { classroom is active and interesting }\end{array}$ & 3.42 & 0.94 \\
\hline $\begin{array}{c}\text { Have a clear understanding of the training } \\
\text { objectives of ideological and political courses }\end{array}$ & 3.42 & 0.84 \\
\hline $\begin{array}{c}\text { Teachers clearly pointed out the expected goals of } \\
\text { ideological and political courses }\end{array}$ & 3.37 & 0.86 \\
\hline $\begin{array}{c}\text { Teachers often encourage us to work towards better } \\
\text { goals in class }\end{array}$ & 3.33 & 0.94 \\
\hline
\end{tabular}

Table 2. Contents of low grouping questions $[(\mathrm{R})$ is a reverse scoring question]

\begin{tabular}{|c|c|c|}
\hline Investigation topic & Mean value (m) & Standard deviation (SD) \\
\hline $\begin{array}{c}\text { Pay attention to examining memory points (R) } \\
\text { during evaluation }\end{array}$ & 2.85 & 0.93 \\
\hline $\begin{array}{c}\text { Improve the implementation of homework } \\
\text { feedback after class }\end{array}$ & 2.71 & 0.90 \\
\hline $\begin{array}{c}\text { After-class homework of ideological and } \\
\text { political course is heavy (R) }\end{array}$ & 2.47 & 0.78 \\
\hline $\begin{array}{c}\text { There are many tasks to be completed, and it is } \\
\text { impossible to fully absorb the understanding } \\
\text { knowledge (R) }\end{array}$ & 2.55 & 0.85 \\
\hline $\begin{array}{c}\text { The study pressure of ideological and political } \\
\text { course is great and the study is exhausted }\end{array}$ & 2.33 & 0.79 \\
\hline
\end{tabular}

\subsubsection{Analysis of comparative learning experience}

Through the comparative analysis of differences, it can be seen that students of different grades and majors have different learning experiences in ideological and political courses, but there is no big difference in overall satisfaction, which does not have the characteristics of comparative analysis. In contrast, the problem of poor learning experience is more obvious than students majoring in science and engineering and art. Some science and engineering students have relatively poor learning experience in teaching content. This situation is mainly caused by the increasing emphasis on the courses in University A, so the teaching system and curriculum design has been affected as the corresponding tasks have been aggravated. In addition, for students majoring in social sciences, the knowledge in ideological and political courses can meet their professional development needs, while those who majoring in science and engineering and art cannot. 
Therefore, teachers need to optimize the content according to student's majors. It should be noted that there are significant differences among different grade groups. It can be seen from Table 3 that the overall satisfaction of freshmen are obviously higher than those of sophomores and juniors. Besides, teaching goals of freshmen and juniors are higher than those of sophomores. However, there are no significant differences between the three sections in terms of burden and evaluation dimension. This is because the ideological and political evaluation methods are consistent and the academic requirements have not changed significantly.

Table 3. Comparison of overall satisfaction and factor differences among students from different grades

\begin{tabular}{|c|c|c|c|}
\hline Dimensions & Grade & Mean value (m) & Standard deviation (SD) \\
\hline \multirow[t]{3}{*}{ Overall satisfaction } & Freshman & 3.49 & 0.76 \\
\hline & Sophomore & 3.06 & 1.03 \\
\hline & Junior & 3.29 & 9.06 \\
\hline \multirow[t]{3}{*}{ Clear goal } & Freshman & 10.35 & 1.71 \\
\hline & Sophomore & 9.10 & 2.25 \\
\hline & Junior & 10.12 & 2.07 \\
\hline \multirow[t]{3}{*}{ Good teaching } & Freshman & 20.13 & 3.32 \\
\hline & Sophomore & 17.53 & 4.66 \\
\hline & Junior & 19.85 & 3.25 \\
\hline \multirow[t]{3}{*}{ Generality of skills } & Freshman & 19.20 & 4.04 \\
\hline & Sophomore & 16.27 & 4.96 \\
\hline & Junior & 17.24 & 4.96 \\
\hline \multirow[t]{3}{*}{ Moderate burden } & Freshman & 10.76 & 1.79 \\
\hline & Sophomore & 10.49 & 2.13 \\
\hline & Junior & 11.18 & 1.90 \\
\hline \multirow[t]{3}{*}{ Evaluation is reasonable } & Freshman & 5.85 & 1.58 \\
\hline & Sophomore & 6.13 & 1.53 \\
\hline & Junior & 5.41 & 1.69 \\
\hline
\end{tabular}

4. Suggestions on Improvement of Learning Experience of Social Science Students' Ideological and Political Studies

It can be seen from the above that social science students are generally satisfied. Moreover, there is no obvious difference between genders and majors. But there are differences between students of various grades, among which the difference between freshmen and sophomores is the most obvious. From the results of correlation analysis, the overall satisfaction has a close relationship with teaching, skills, burden and other issues.

4.1 Further improve the content of education and teaching

Ideological and political learning includes courses of Ideological and Moral Cultivation and Legal Basis, Introduction to Mao Zedong Thought and Theoretical System of Socialism with Chinese Characteristics, Situation and Policy, etc. Both questionnaire and interview indicate that students pay more attention to the effectiveness of classroom content than presentation methods. Therefore, teachers should keep abreast of current hot news and affairs in the teaching process, and fully enhance the vividness and effectiveness of teaching content to improve learning experience. Social science students 
need to have a full understanding of social development. Therefore, by starting with students' real life, teachers need to choose teaching content based on students' characteristics while instilling ideological and political theory knowledge to teach students in accordance with their aptitude. In the new era and situation, teachers must guide students to take initiatives to pay attention to current affairs hot spots, such as ideology, politics and morality around them to improve professional ability.

\subsection{Further develop the classroom teaching mode}

Teaching in large classes is not conducive to the comprehensive development of social science students, and the learning experience can not be significantly improved. Therefore, the method of large class teaching and group discussion can be adopted to improve students' participation to realize deep learning. Teachers can use the method in each group to improve the feedback of schoolwork, so that students will have better development. Teachers need to give full play to their guiding role. In the interview survey, social science students are looking forward to getting teachers' feedback and guidance. Therefore, teachers should expand and guide the teaching process, stimulate participation of students, help them solve specific problems, and improve their learning experience. Teachers should also give positive guidance and systematic feedback from thoughts and actions when students completing their schoolwork. Besides, it is necessary to encourage students to complete their schoolwork and practice with high efficiency and quality by means of group cooperation. On this basis, students will integrate the received teaching knowledge into real life, and change to active inquiry from passive learning, thereby significantly improving the learning experience. In addition, it is necessary to enrich the assessment methods and improve the adaptability of the classroom, such as students' self-evaluation, mutual evaluation, achievement sharing and social practice records.

\section{Conclusions}

In summary, the ideological and political course featuring important task of moral education, plays an important role in the university education system. The teaching effect is directly related to the growth and development, especially for social science students. However, from the practical research, there are still many factors that restrict the improvement of the teaching effect of ideological and political courses, and some students have poor learning experience. By carrying out teaching reform with diversified teaching methods, teachers, facing with these issues, should raise their awareness to improve students' professional knowledge and moral quality to become comprehensive talents for society.

\section{Conflicts of Interest}

The author declares no conflicts of interest regarding the publication of this paper.

\section{References}

[1] Li C., Deng Z. and Ruan Q. (2019). Investigation on the Learning Experience of Ideological and Political Courses of Social Science Students (in Chinese). Social Sciences Journal of Universities in Shanxi, 31(11): 57-64.

[2] Gao Q. (2019). Investigation and Thinking on Key and Difficult Problems in the Course of Marxism and Social Science Methodology (in Chinese). Leading Journal of Ideological \& Theoretical Education, (11): 112-115.

[3] Fan Z. (2018). Effect of Art Class on the Cultivation of Lateral Capacity in Vocational College Students: Based on the Investigation on the Students in Northern Beijing Vocational Education Institutes. Chinese Medical Ethics, 31(2): 252259.

[4] Li X. Y. and Jin Y. X. (2019). Humanities and Social Sciences Postgraduate Research Method Study Application Study -- Also on the Construction of Postgraduate Research Method Course System. Research in Teaching, (3): 34-38+43. 